\title{
Pengembangan mobile learning berbasis articulate storyline 3 pada mata pelajaran kearsipan untuk meningkatkan self regulated learning dan hasil belajar siswa (studi pada kelas $\mathrm{x}$ OTKP di SMK Cendika Bangsa Kepanjen)
}

\author{
Susi Fardila, Mohammad Arief* \\ Universitas Negeri Malang, Jl. Semarang No. 5 Malang, Jawa Timur, Indonesia \\ *Penulis korespondensi, Surel: mohammad.arief.fe@um.ac.id
}

Paper received: 1-4-2021; revised: 22-4-2021; accepted: 29-4-2021

\begin{abstract}
Abstrak
Pembelajaran daring di masa pandemic covid 19 ini menuntut tenaga pendidik untuk lebih kreatif dan inovatif dalam melaksanakan pembelajaran agar siswa lebih mudah memahami materi pelajaran. Berkaitan dengan hal tersebut, maka pengembangan media pembelajaran perlu untuk dilakukan dengan memanfaatkan teknologi yang sudah berkembang saat ini. Penelitian dan pengembangan ini bertujuan untuk Menghasilkan Mobile Learning berbasis Articulate Storyline 3 pada Mata Pelajaran Kearsipan pada siswa kelas X OTKP di SMK Cendika Bangsa Kepanjen. Penelitian ini menggunakan model penelitian dan pengembangan (R\&D) dengan langkah-langkah Borg and Gall yang telah dimodifikasi. Teknik analisis data yang digunakan adalah deskriptif persentase dan uji independent sample t-test serta uji n-gain. Hasil penelitian dan pengembangan ini adalah m-learning pada mata pelajaran Kearsipan bernama MoLfAS yang telah dinyatakan sangat valid dan layak digunakan dalam pembelajaran kearsipan oleh ahli media, ahli materi, dan 6 siswa uji coba kelompok kecil serta terbukti dapat meningkatkan self-regulated learning dan hasil belajar peserta didik secara signifikan pada saat sebelum dan sesudah menggunakan m-learning. Sehingga dapat disimpulkan bahwa MoLfAS layak dan efektif digunakan sebagai media pembelajaran untuk meningkatkan selfregulated learning dan hasil belajar peserta didik pada mata pelajaran Kearsipan.
\end{abstract}

Kata kunci: mobile learning; articulate storyline; kearsipan self-regulated learning; hasil belajar

\section{Pendahuluan}

Pandemi covid-19 yang terjadi di Indonesia sejak awal Maret hingga saat ini membawa banyak perubahan dalam segala bidang Sejak mewabahnya pandemic covid 19 ini pemerintah Indonesia telah mengeluarkan berbagai kebijakan guna meminimalisir tingkat penyebaran covid 19 dengan diberlakukannya social distancing, physical distancing, hingga pemberlakuan pembatasan sosial berskala besar di berbagai daerah (Fitriyani, 2020) . Kebijakan dalam bidang pendidikan selama masa pandemi covid 19 ini diatur dalam Surat Edaran No 4 Tahun 2020 yang dikeluarkan oleh Menteri Pendidikan dan Kebudayaan Republik Indonesia yang meliputi 4 poin utama. Pertama, pembelajaran dilakukan secara daring/jarak jauh. Kedua, belajar dari rumah difokuskan pada pendidikan kecakapan hidup. Ketiga, aktivitas dan tugas pembelajaran belajar dari rumah dapat bervariasi antar siswa, sesuai minta dan kondisi masing-masing termasuk mempertimbangkan kesenjangan akses belajar dirumah. Keempat, bukti atau produk aktivitas belajar dari rumah diberikan umpan balik dan berguna dari guru (Kemendikbud, 2020).

Mobile learning merupakan pembelajaran yang menggunakan teknologi atau perangkat mobile seperti handphone, tablet pc, laptop, dll. Mobile learning sangat mudah diakses oleh pengguna kapan saja dan dimana saja tanpa terikat tempat dan waktu. (Jalinus and Ambiyar,

This work is licensed under a Creative Commons Attribution-ShareAlike 4.0 International License. 
2016) menyatakan bahwa m-learning merupakan pembelajaran yang menggunakan perangkat mobile seperti smartphone, laptop dan peralatan teknologi informasi lainnya, pembelajaran ini juga tidak terbatas waktu dan tempat penggunaannya, dapat dikondisikan sendiri oleh pengguna atau peserta didik, sehingga sangat tepat jika digunakan pada saat pembelajaraan dari rumah atau daring. Pembelajaran mobile learning memiliki dampak positif bagi pembelajaran karena melalui mobile learning, siswa dapat berhubungan dengan guru serta peserta didik lainnya dengan mengandalkan koneksi dari internet (Rahmat et al., 2019). Materi yang disajikan tidak hanya berupa teks, namun peserta didik dapat melihat maupun mendengar tampilan grafis, audio, dan video pembelajaran yang menarik (Rizal, Satrio and Wirawan, 2013). Sehingga media pembelajaran interaktif ini mampu membuat peserta didik lebih aktif dan memiliki motivasi tinggi dalam belajar (Rohmah and Bukhori, 2020).

Mobile learning yang dikembangkan oleh peneliti yaitu menggunakan software articulate storyline 3 yang merupakan perangkat lunak (software) yang digunakan sebagai alat komunikasi atau media presentasi dengan template yang dapat dibuat sendiri atau bahkan dapat membuat presentasi dengan template yang disediakan dan dapat menyesuaikan karakter sesuai selera (Rafmana and Chotimah, 2018). Output dari articulate storyline dikonversikan atau dipublikasikan dalam bentuk html5, articulate online, .lms, .CD, .word dan juga memberikan dukungan untuk mobile application (Android atau iOS). Mobile learning dikembangkan secara interaktif dapat meningkatkan semangat belajar mandiri peserta didik dirumah.

Vrieling (dalam Pratama, 2019) dalam penelitiannya menyatakan bahwa murid akan mengalami pertambahan prestasi yang signifikan di dalam lingkungan pembelajaran dengan adanya peningkatan kemandirian belajar. Peserta didik yang mampu melakukan self-regulated learning, memiliki gambaran yang jelas tentang bagaimana dan mengapa strategi pengaturan mandiri tertentu harus digunakan (Cheng, 2011). Zimmeran (dalam Kristiyani, 2016) mendefinisikan strategi pengukuran self-regulated learning, yaitu evaluasi diri, inisiatif, penetapan dan perencanaan tujuan belajar, mencari informasi sumber belajar lainnya, pencatatan materi dan pemantauan perkembangan belajar, pengaturan lingkungan belajar, konsekuensi diri, pemahaman materi, berdiskusi atau bertanya, dan membaca kembali catatan atau hasil ujian. Self-regulated learning memiliki dampak positif bagi peserta didik dimana dengan adanya kemandirian belajar dapat meningkatkan hasil belajar para peserta didik baik aspek afektif, kognitif maupun psikomotoriknya .Secara umum keadaan lingkungan belajar yang kondusif adalah faktor terbaik untuk memperoleh keterampilan self-regulated learning (Boekaerts, 1999). Pembelajaran mandiri merupakan salah satu prediktor hasil belajar (Marlina, 2017:75). Hasil belajar merupakan hal paling penting dalam pembelajaran, karena akan menghasilkan perubahan tingkah laku, yang mencakup aspek kognitif, afektif, psikomotorik (Sudjana, 2014:22). Beberapa penelitian sebelumnya juga telah membuktikan bahwa media pembelajaran mampu meningkatkan self-regulated learning, hasil belajar dan efektif memaksimalkan pemahaman konseptual peserta didik (Ghozali, F. A. And Rusimamto, 2016), (Saefi, Lukiati and Suarsini, 2017).

Berdasarkan hasil observasi dan wawancara di SMK Cendika Bangsa, bahwa pembelajaran di masa pandemic covid 19 ini dilaksanakan secara semi daring, maksudnya kompetensi dasar yang hanya berupa materi disampaikan secara daring melalui Google Classroom dan kompetensi dasar berupa praktik dilakukan secara luring dengan waktu yang terbatas dan tetap mengikuti protokol kesehatan. Pada pembelajaran daring peserta didik 
diberikan ringkasan materi pembelajaran berupa handout yang dibuat oleh guru secara sederhana. Terbatasnya media pembelajaran yang sangat sederhana mengakibatkan peserta didik malas untuk membaca dan memahami materi yang disajikan karena hanya berupa teks dan beberapa gambar saja. Mata pelajaran kearsipan mewajibkan peserta didik untuk bisa mempraktikan pengelolaan dan penyimpanan kearsipan. Karena penyampaian materi dilakukan secara daring dan media yang digunakan sebagian besar hanya teks saja, akibatnya peserta didik kurang memahami materi secara optimal dan pada saat evaluasi baik mengerjakan latihan soal maupun praktik kearsipan hasil belajar mereka kurang memuaskan dan banyak yang mendapat nilai dibawah KKM. Fasilitas pembelajaran daring yang menunjang peserta didik adalah Smartphone. Namun penggunaan smartphone dalam pembelajaran daring belum digunakan secara optimal. Peneliti memiliki inovasi untuk mengemas atau mengembangkan Mobile Learning berbasis Articulate Storyline 3 sebab smartphone memiliki potensi yang tinggi jika digunakan dengan maksimal. Media ini berupa sebuah aplikasi yang dapat didownload dalam smartphone masing-masing peserta didik dengan pengemasan materi berupa teks dan video dengan desain yang menarik.

Berdasarkan penelitian sebelumnya yang relevan mengenai media pembelajaran articulate storyline yang sudah pernah dilakukan oleh (Nabilah, 2020) bahwa hasil penelitian menunjukan bahwa media pembelajaran articulate storyline dalam kategori sangat baik dan dapat digunakan sebagai media pembelajaran dan penelitian ini diharapkan dapat menjadi acuan dalam melakukan penelitian dan pengembangan. Penelitian kedua oleh (Mumtahana, 2020) bahwa media dengan articulate Storyline memiliki pengaruh yang sangat besar dalam meningkatkan hasil belajar dan respon siswa dalam kegiatan pembelajaran. Penelitian ketiga oleh (Rohmah and Bukhori, 2020) bahwa media pembelajaran interaktif berbasis android mata pelajaran korespondensi menggunakan Articulate Storyline 3 pada yang dihasilkan telah layak untuk dijadikan sebagai media pembelajaran. Sehingga dapat disimpulkan bahwa media ini sangat layak dan dapat digunakan sebagai inovasi kegiatan pembelajaran jarak jauh untuk mendukung kemandirian belajar, sehingga meningkatkan hasil belajar peserta didik.

\section{Metode}

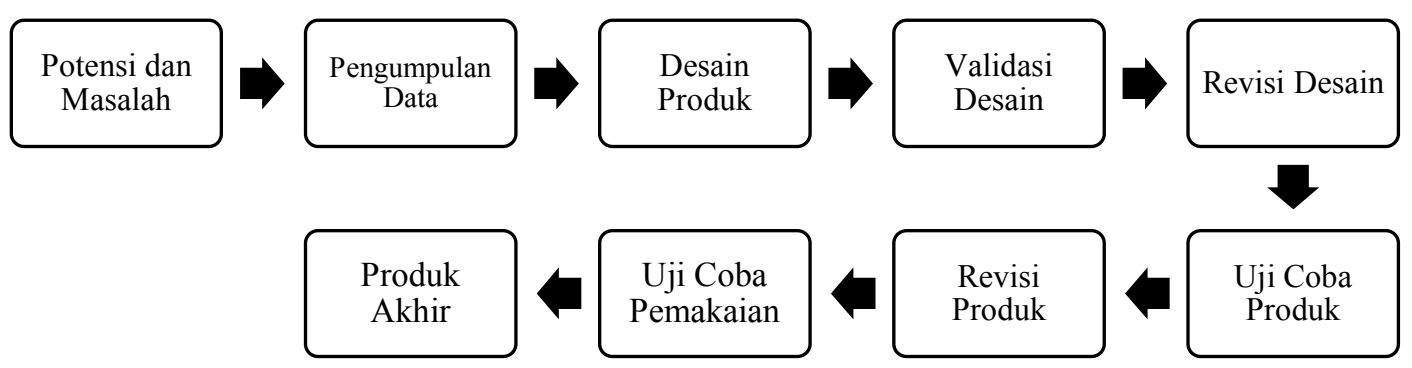

Gambar 1. Tahapan Prosedur Penggunaan Metode Research and Development (R\&D)

Prosedur penelitian dan pengembangan yang digunakan mengikuti langkah-langkah metode Borg and Gall (Sugiyono, 2015: 408-409). Penelitian dan pengembangan ini menggunakan sembilan metode pengembangan karena dirasa sesuai dengan kebutuhan penelitian dan pengembangan yang dilakukan. Langkah-langkah penelitian dan pengembangan yang pertama adalah menemukan potensi dan masalah yang terjadi selama pembelajaran daring maupun luring di SMK Cendika Bangsa Kepanjen melalui wawancara dan 
observasi. Langkah kedua, mengumpulkan informasi dari hasil observasi dan wawancara terkait potensi dan masalah yang ditemukan. Langkah ketiga, melakukan desain produk dengan membuat media menggunakan Articulate Storyline 3 sesuai dengan rancangan yang sesuai dengan langkah sebelumnya. Langkah keempat, melakukan validasi untuk mengetahui nilai kelayakan dari produk yang dikembangkan melalui validasi oleh ahli media dan ahli materi. Langkah kelima, setelah mendapatkan validasi dari ahli media dan ahli materi, selanjutnya dilakukan revisi terhadap media yang dikembangkan, dasar revisi media ini diperoleh dari saran dan kritik ahli materi maupun ahli media. Langkah keenam, di uji cobakan pada kelompok kecil dengan jumlah enam peserta didik kelas X OTKP dengan kemampuan akademis yang berbeda, yaitu dua peserta didik berkemampuan tinggi, dua peserta didik berkemampuan sedang, dan dua peserta didik berkemampuan rendah. Pada uji coba kelompok kecil ini siswa diberikan angket untuk mengetahui respon terhadap media pembelajaran yang sudah tervalidasi oleh ahli materi dan ahli media. Langkah ketujuh, Revisi produk dilakukan setelah tahap uji coba terhadap kelompok kecil. Langkah kedelapan, Setelah dilakukan uji coba produk dan revisi produk, maka dilakukan uji coba pemakaian. Uji coba pemakaian dilakukan pada kelas kontrol (yang tidak menggunakan mobile learning interaktif) dan kelas eksperimen (yang menggunakan mobile learning interaktif). Uji coba pemakaian ini dilakukan untuk mengetahui perbedaan Self-Regulated Learning dan hasil belajar (kognitif dan psikomotorik) siswa pada kelas kontrol dan kelas eksperimen. Langkah terakhir, Setelah uji coba pemakaian berjalan dengan baik, maka aplikasi Mobile learning dapat di publish dan dapat diunduh secara online melalui link yang dibagikan oleh pengembang.

Jenis data analisis yang digunakan adalah data kualitatif dan kuantitatif. Data kualitatif merupakan kritik, saran dan komentar yang diberikan validator dan peserta didik atas produk yang dikembangkan. Data kuantitatif diperoleh dari perhitungan skor kuesioner validator dan peserta didik sebagai subjek uji coba serta hasil kuesioner self-regulated learning dan hasil belajar dari posttest peserta didik yang dianalisis menggunakan independent sample t-test dengan bantuan SPSS 21.

\section{Hasil dan Pembahasan}

Produk yang dihasilkan dalam penelitian dan pengembangan ini adalah Mobile Learning Interaktif pada mata kearsipan KD 3.7 Menerapkan penyimpanan arsip sistem abjad, kronologis, geografis, nomor, dan subjek. Media Pembelajaran ini bernama MoLfAS (Mobile Learning for Archive Storage) yang dapat diakses oleh pengguna android minimal versi 5.0 atau lollipop. Secara umum MoLfAS (Mobile Learning for Archive Storage) ini ditujukan kepada peserta didik kelas X OTKP di SMK Cendika Bangsa Kepanjen. MoLfAS tersedia secara gratis pada link https://bit.ly/apkMoLfAS. Berikut tampilan beserta fitur-fitur MoLfAS yang telah dikembangkan oleh peneliti: 


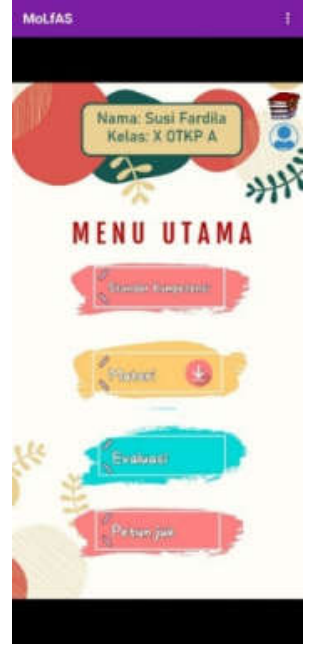

Gambar 2. Menu Utama
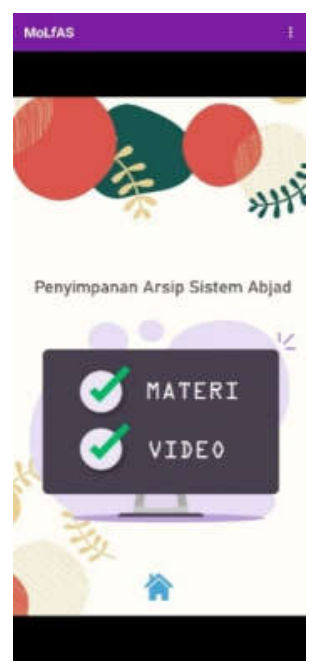

Gambar 3. Pilihan Materi

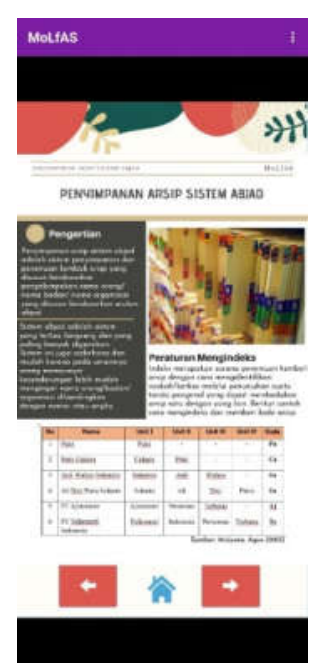

Gambar 4. Materi

Setelah memahami pembelajaran pengguna dapat melakukan evaluasi melalui menu latihan soal, dan dapat melaporkan hasil nilai yang telah dicapai dengan klik button "Laporkan Nilai" kepada guru melalui WhatApp.

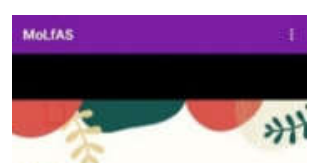

LATIHAN SOAL

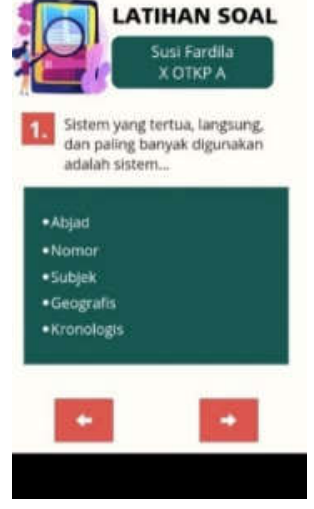

Gambar 5. Latihan Soal
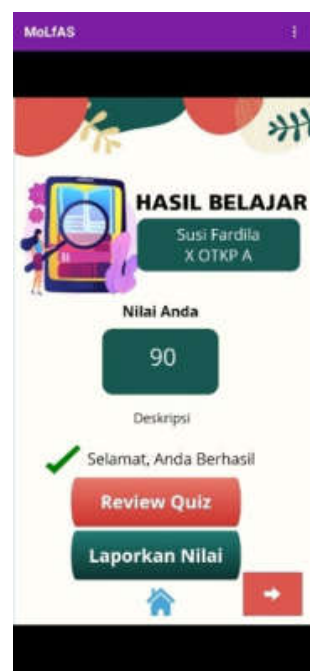

Gambar 6. Hasil Belajar
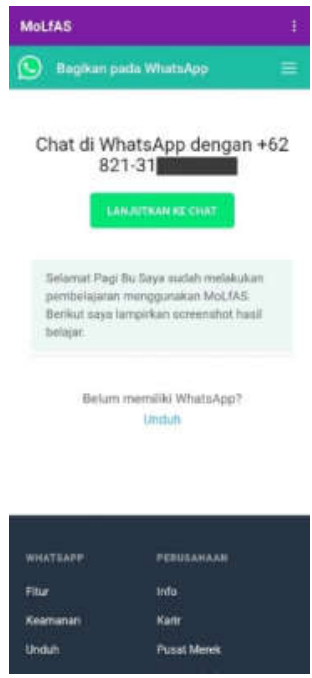

Gambar 7. Laporkan nilai

Hasil validasi $M$-Learning oleh ahli materi, ahli media, dan siswa uji coba kelompok kecil secara keseluruhan disajikan dalam Tabel 1 berikut ini:

Tabel 1. Data hasil validasi keseluruhan

\begin{tabular}{clll}
\hline No & Validasi & Persentase & Kriteria Validitas \\
\hline 1. & Ahli Materi & $96 \%$ & Sangat Valid \\
\hline 2. & Ahli Media & $92 \%$ & Sangat Valid \\
\hline 3. & Siswa Uji Coba Kelompok Kecil & $97 \%$ & Sangat Valid \\
\hline & Rata-rata & $95 \%$ & Sangat Valid
\end{tabular}

Table used by permission (CFardila, Susi. 2021. Data hasil validasi keseluruhan. 
Berdasarkan Tabel 1, diketahui rata-rata persentase validasi secara keseluruhan sebesar 95\%, sehingga dapat disimpulkan bahwa media pembelajaran MoLfAS yang dikembangkan peneliti dinyatakan 'Sangat Valid' dan layak digunakan dalam pembelajaran Kearsipan di SMK Cendika Bangsa Kepanjen. Hal ini sejalan dengan penelitian sebelumnya, dimana hasil validasi ahli materi, ahli media dan uji coba kelompok kecil dijadikan dasar penentuan apakah media pembelajaran yang dikembangkan layak atau tidak digunakan dalam pembelajaran (Alhafidz, M. R. L. And Haryono, 2018) (Mas'adah, 2019). Pengembangan media pembelajaran tidaklah cukup dengan mendapatkan nilai, tetapi dilengkapi dengan saran yang harus dipenuhi oleh pengembang untuk mencapai pengembangan media pembelajaran yang diharapkan oleh validator ahli (Arwanda, Irianto and Andriani, 2020)

Hal ini senada dengan penelitian sebelumnya, dimana hasil validasi ahli materi, ahli media dan uji coba kelompok kecil dijadikan dasar penentuan apakah media pembelajaran yang dikembangkan layak atau tidak digunakan dalam pembelajaran (Rohmah and Bukhori, 2020), (Andito, M. S. R. And Supriadi, 2020).

Tabel 2. Hasil analisis data self-regulated learning

\begin{tabular}{|c|c|c|c|c|c|c|c|}
\hline \multirow{3}{*}{ Aspek } & \multicolumn{7}{|c|}{ Total Skor } \\
\hline & \multicolumn{3}{|c|}{$\begin{array}{l}\text { Kuesioner Kelas } \\
\text { Kontrol }\end{array}$} & \multicolumn{3}{|c|}{$\begin{array}{l}\text { Kuesioner Kelas } \\
\text { Eksperimen }\end{array}$} & \multirow{2}{*}{$\begin{array}{l}\text { Kenaikan } \\
\%\end{array}$} \\
\hline & $\mathbf{X}$ & $\%$ & Kriteria & $\mathbf{X}$ & $\%$ & Kriteria & \\
\hline Evaluasi diri & 145 & $64 \%$ & Sedang & 195 & $87 \%$ & Tinggi & $23 \%$ \\
\hline $\begin{array}{l}\text { Mengatur dan } \\
\text { menyusun } \\
\text { klasifikasi }\end{array}$ & 44 & $58 \%$ & Rendah & 64 & $85 \%$ & Tinggi & $27 \%$ \\
\hline $\begin{array}{l}\text { Menetapkan tujuan } \\
\text { perencanaan }\end{array}$ & 87 & $58 \%$ & Rendah & 132 & $88 \%$ & Tinggi & $30 \%$ \\
\hline Mencari informasi & 39 & $52 \%$ & Rendah & 67 & $89 \%$ & Tinggi & $15 \%$ \\
\hline $\begin{array}{l}\text { Menyimpan catatan } \\
\text { dan mementau }\end{array}$ & 41 & $55 \%$ & Rendah & 65 & $87 \%$ & Tinggi & $32 \%$ \\
\hline $\begin{array}{l}\text { Mengatur } \\
\text { Lingkungan }\end{array}$ & 43 & $57 \%$ & Rendah & 64 & $85 \%$ & Tinggi & $28 \%$ \\
\hline Konsekuensi diri & 87 & $58 \%$ & Rendah & 134 & $89 \%$ & Tinggi & $31 \%$ \\
\hline $\begin{array}{l}\text { Berlatih dan } \\
\text { mengingat }\end{array}$ & 93 & $62 \%$ & Sedang & 133 & $89 \%$ & Tinggi & $27 \%$ \\
\hline $\begin{array}{l}\text { Mencari dukungan } \\
\text { sosial }\end{array}$ & 47 & $67 \%$ & Sedang & 65 & $87 \%$ & Tinggi & $20 \%$ \\
\hline Memeriksa catatan & 45 & $60 \%$ & Sedang & 68 & $91 \%$ & Sangat Tinggi & $31 \%$ \\
\hline Jumlah & 671 & $60 \%$ & Sedang & 987 & $88 \%$ & Tinggi & $28 \%$ \\
\hline
\end{tabular}

Berdasarkan Tabel 2, terjadi peningkatan untuk setiap indikator self-regulated learning sebelum dan sesudah menggunakan mobile learning. Rata-rata self-regulated learning yang tidak menggunakan mobile learning sebesar $60 \%$ berada pada tingkat kategori sedang, namun setelah dilakukan pembelajaran menggunakan mobile learning MoLfAS, self-regulated learning peserta didik meningkat dengan rata-rata sebesar $88 \%$ dan berada pada tingkat kategori tinggi. Hasil penelitian ini relevan dengan penelitian yang dilakukan oleh (Meolbatak and Bria, 2016) pengembeangan media pembelajaran berbasis multimedia dapat meningkatkan SelfRegulated Learning dengan analisis akhir menggunakan bantuan SPSS.

Data hasil belajar peserta didik diperoleh dari perbandingan nilai hasil belajar yang tidak menggunakan MoLfAS, yaitu pembelajaran menggunakan bahan ajar handout dan nilai 
hasil belajar setelah pembelajaran menggunakan MoLfAS. Penelitian ini dilakukan secara luring, karena bertepatan dengan jadwal masuk kelas X OTKP yang dilakukan secara bergantian satu minggu sekali, meskipun dilakukan secara luring tetap melaksanakan protokol kesehatan yang ada. Pemberian petunjuk, pengunduhan, penginstalan dan penggunaan aplikasi dilakukan menggunakan LCD Proyektor, setelah memahami materi yang tersaji dalam MoLfAS, peserta didik diarahkan pada menu Latihan Soal untuk mengevaluasi pembelajaran yang telah dilakukan. Pengolahan analisis hasil belajar kognitif dan psikomotorik peserta didik dipaparkan pada tabel sebagai berikut.

\subsection{Hasil belajar kognitif}

Berikut hasil belajar kognitif peserta didik kelas kontrol (yang tidak menggunakan MoLfAS) dan kelas eksperimen kontrol (yang menggunakan MoLfAS),

Tabel 3. Hasil belajar kognitif kelas kontrol dan kelas eksperimen peserta didik

\begin{tabular}{cllll}
\hline \multirow{2}{*}{ No. Absen } & \multicolumn{2}{c}{ Kelas Kontrol } & \multicolumn{2}{c}{ Kelas Eksperimen } \\
\cline { 2 - 5 } & Nilai & Ketercapaian KKM (75) & Nilai & Ketercapaian KKM (75) \\
\hline Rata-rata & 75 & $60 \%$ & 86 & $87 \%$ \\
\hline
\end{tabular}

Table used by permission Fardila, Susi. 2021. Data hasil belajar kognitif kelas kontrol dan kelas eksperimen peserta didik

Pada Tabel 3 diketahui bahwa hasil rata-rata nilai kognitif kelas kontrol yaitu hasil belajar yang diambil dari proses pembelajaran menggunakan bahan ajar handout sebesar 75 dan persentase tingkat ketuntasan rata-rata kelas adalah $60 \%$ sedangkan hasil rata-rata nilai kognitif kelas eksperimen yang menggunakan media pembelajaran MoLfAS rata-rata nilai kelas sebesar 86 dan persentase tingkat ketuntasan rata-rata kelas meningkat menjadi 87\%. Selanjutnya untuk mengetahui tingkat perbedaan signifikan pada hasil belajar peserta dilakukan analisis data menggunakan Uji T. Analisis data hasil belajar peserta didik menggunakan Uji T karena data sample kurang dari seratus. Uji T yang digunakan adalah Paired Sample T-test dengan bantuan perhitungan menggunakan SPSS 21. Hasil analisis dipaparkan sebagai berikut:

\subsubsection{Uji Normalitas}

Independent Sample T-test merupakan bagian dari Statistik Parametic, sehingga sebelum melakukan uji Independent Sample T-test, data sampel harus normal. Maka dari itu dilakukan uji normalitas, yang hasilnya dipaparkan pada Tabel 4 berikut ini.

Tabel 4. Uji normalitas hasil belajar kognitif

\begin{tabular}{lllll}
\hline \multirow{2}{*}{ Kelas } & \multicolumn{4}{c}{ Shapiro-Wilk } \\
\cline { 2 - 5 } & Statistic & Df & Sig. \\
\hline \multirow{2}{*}{ Hasil Belajar } & Kelas kontrol & .937 & 15 & .349 \\
\cline { 2 - 5 } & Kelas eksperimen & .937 & 15 & .250 \\
\hline
\end{tabular}

Table used by permission Fardila, Susi. 2021. Data uji normalitas hasil belajar kognitif

Uji normalitas menggunakan Shapiro-Wilk karena sampel yang diuji berjumlah kurang dari 50. Data dikatakan normal jika nilai sig $>0,05$. Hasil signifikasi kelas kontrol adalah 0,349 
dan signifikasi kelas eksperimen adalah 0,250 yang berarti nilai sig. lebih dari 0,05 dan dapat disimpulkan bahwa semua data yang dianalisis berdistribusi normal.

\subsubsection{Independent Sample T-test}

Pada Tabel 5 tersebut, terdapat ringkasan hasil statistik dari sampel sebelum dan sesudah diberi perlakuan. Nilai mean kuesioner kelas kontrol 75.00 dan mean kuesioner kelas eksperimen setelah diberi perlakuan adalah 86.00 dengan jumlah responden sebanyak 15 orang. Hasil nilai mean pada kelas eksperimen > kelas kontrol, maka secara deskriptif terdapat perbedaan rata rata tingkat hasil belajar kognitif antara kelas kontrol dan kelas eksperimen. Untuk mengetahui apakah perbedaan tersebut signifikan maka diperlukan uji Independent Sample T-test, seperti pada Tabel 6.

Tabel 5. Independent samples statistic hasil belajar

\begin{tabular}{llllll}
\hline & & Mean & N & Std. Deviation & Std. Error Mean \\
\hline Hasil & Kontrol & 75.00 & 15 & 9.81981 & 2.53546 \\
\cline { 2 - 6 } Belajar & Eksperimen & 86.00 & 15 & 9.48683 & 2.44949 \\
\hline $\begin{array}{l}\text { Tabled used by permission Fardila, Susi. 2021. Data hasil uji Independent Samples Statistic } \\
\text { Hasil Belajar }\end{array}$
\end{tabular}

Tabel 6. Uji independent sample t-test hasil belajar

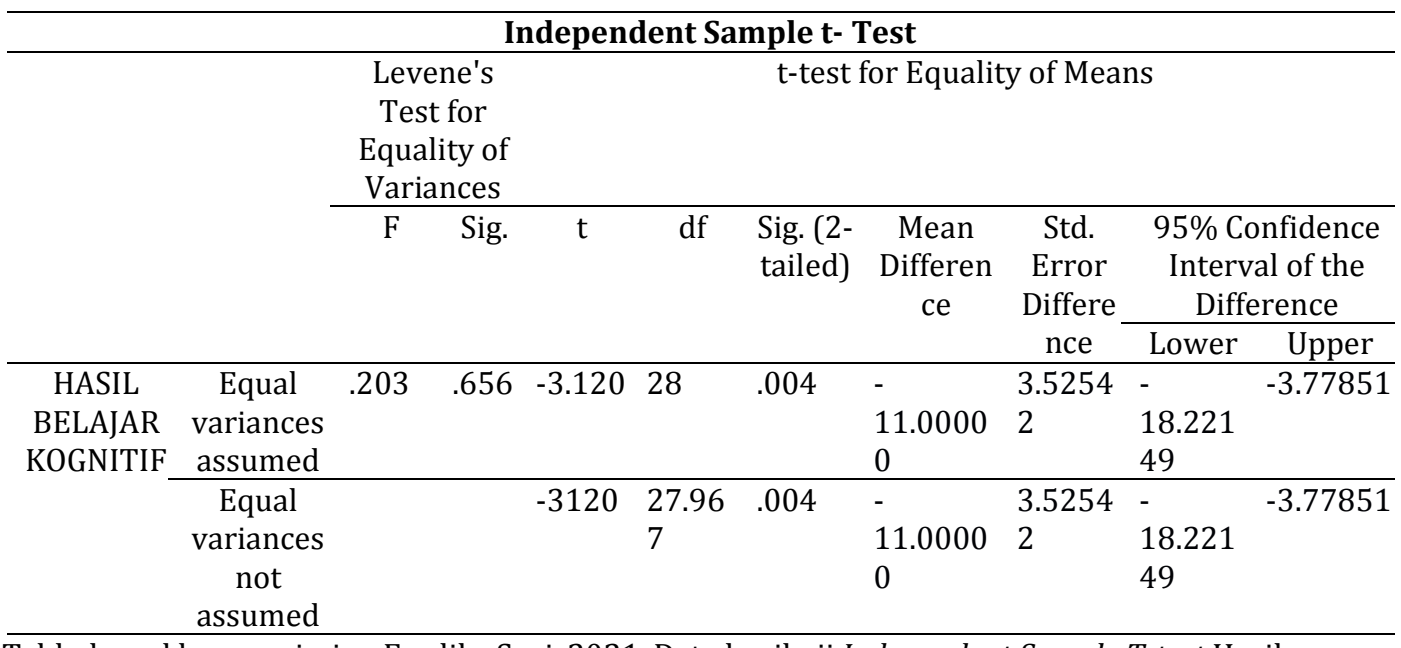

Tabled used by permission Fardila, Susi. 2021. Data hasil uji Independent Sample T-test Hasil Belajar Kognitif

Hasil nilai Sig. ( 2 tailed) antara kelas kontrol dan kelas eksperimen adalah 0.004 yang berarti nilai ini kurang dari $0,05(0.004<0,05)$ dapat diartikan, bahwa terdapat perbedaan yang sangat signifikan pada hasil belajar kognitif peserta didik antara kelas kontrol dan kelas eksperimen.

\subsubsection{Uji N-gain}

Uji N-gain dilakukan jika terdapat pengaruh signifikan sebelum dan sesudah implementasi media pembelajaran yang dikembangkan. Uji peningkatan rata-rata dilakukan 
untuk mengetahui besarnya peningkatan hasil belajar peserta didik kelas kontrol dan kelas eksperimen menggunakan MoLfAS.

$<g>=\frac{\text { Skor kelas eksperimen }- \text { Skor kelas kontrol }}{\text { Skor ideal }- \text { Skor kelas kontrol }}$

$<g>=\frac{1290-1125}{1500-1125}$

$<g>=0,4$

Berdasarkan perhitungan diatas nilai hasil belajar peserta didik kelas kontrol dan kelas eksperimen diperoleh nilai n-gain sebesar 0,4 atau dapat disimpulkan bahwa peningkatan hasil belajar peserta didik dalam kategori sedang.

\subsection{Hasil belajar psikomotorik}

Berikut hasil belajar psikomotorik peserta didik kelas kontrol (yang tidak menggunakan MoLfAS) dan kelas eksperimen kontrol (yang menggunakan MoLfAS.

Tabel 7. Hasil belajar psikomotorik kelas kontrol dan kelas eksperimen peserta didik

\begin{tabular}{cllll}
\hline \multirow{2}{*}{ No. Absen } & \multicolumn{2}{c}{ Kelas Kontrol } & \multicolumn{2}{c}{ Kelas Eksperimen } \\
\cline { 2 - 5 } & Nilai & $\begin{array}{l}\text { Ketercapaian KKM } \\
(75)\end{array}$ & Nilai & Ketercapaian KKM (75) \\
\hline Rata-rata & 80 & $53 \%$ & 89 & $86 \%$ \\
\hline
\end{tabular}

Table used by permission Fardila, Susi. 2021. Data hasil belajar kognitif kelas kontrol dan kelas eksperimen peserta didik

Pada Tabel 7 diketahui bahwa hasil rata-rata nilai psikomotorik kelas kontrol yaitu hasil belajar yang diambil dari proses pembelajaran menggunakan bahan ajar handout sebesar 780 dan persentase tingkat ketuntasan rata-rata kelas adalah 53\% sedangkan hasil rata-rata nilai kognitif kelas eksperimen yang menggunakan media pembelajaran MoLfAS rata-rata nilai kelas sebesar 89 dan persentase tingkat ketuntasan rata-rata kelas meningkat menjadi 86\%. Selanjutnya untuk mengetahui tingkat perbedaan signifikan pada hasil belajar peserta dilakukan analisis data menggunakan Uji T. Analisis data hasil belajar peserta didik menggunakan Uji T karena data sample kurang dari seratus. Uji T yang digunakan adalah Paired Sample T-test dengan bantuan perhitungan menggunakan SPSS 21. Hasil analisis dipaparkan sebagai berikut:

\subsubsection{Uji Normalitas}

Independent Sample T-test merupakan bagian dari Statistik Parametic, sehingga sebelum melakukan uji Independent Sample T-test, data sampel harus normal. Maka dari itu dilakukan uji normalitas, yang hasilnya dipaparkan pada Tabel 8 berikut ini.

Tabel 8. Uji normalitas hasil belajar kognitif

\begin{tabular}{lllll}
\hline \multirow{2}{*}{ Kelas } & \multicolumn{4}{c}{ Shapiro-Wilk } \\
\cline { 2 - 5 } & Statistic & Df & Sig. \\
\hline \multirow{2}{*}{ Hasil Belajar } & Kelas kontrol & .952 & 15 & .349 \\
\cline { 2 - 5 } & Kelas eksperimen & .884 & 15 & .054 \\
\hline
\end{tabular}

Table used by permission Fardila, Susi. 2021. Data uji normalitas hasil belajar kognitif 
Uji normalitas menggunakan Shapiro-Wilk karena sampel yang diuji berjumlah kurang dari 50. Data dikatakan normal jika nilai sig $>0,05$. Hasil signifikasi kelas kontrol adalah 0,349 dan signifikasi kelas eksperimen adalah 0,054 yang berarti nilai sig. lebih dari 0,05 dan dapat disimpulkan bahwa semua data yang dianalisis berdistribusi normal.

\subsubsection{Independent Sample T-test}

Tabel 9. Independent samples statistic hasil belajar

\begin{tabular}{llrrrr}
\hline & & Mean & N & Std. Deviation & \multicolumn{1}{c}{ Std. Error Mean } \\
\hline Hasil & Kontrol & 80.13 & 15 & 6.47927 & 1.67294 \\
\cline { 2 - 6 } Belajar & Eksperimen & 88.93 & 15 & 7.16606 & 1.85027 \\
\hline
\end{tabular}

Tabled used by permission Fardila, Susi. 2021. Data hasil uji Independent Samples Statistic Hasil Belajar

Pada Tabel 9 terdapat ringkasan hasil statistik dari sampel sebelum dan sesudah diberi perlakuan. Nilai mean kuesioner kelas kontrol 80.13 dan mean kuesioner kelas eksperimen setelah diberi perlakuan adalah 88.93 dengan jumlah responden sebanyak 15 orang. Hasil nilai mean pada kelas eksperimen > kelas kontrol, maka secara deskriptif terdapat perbedaan rata rata tingkat hasil belajar kognitif antara kelas kontrol dan kelas eksperimen. Untuk mengetahui apakah perbedaan tersebut signifikan maka diperlukan uji Independent Sample T-test, seperti pada Tabel 10.

Tabel 10. Uji independent sample t-test hasil belajar

\begin{tabular}{|c|c|c|c|c|c|c|c|c|c|c|}
\hline \multicolumn{11}{|c|}{ Independent Sample t- Test } \\
\hline & & $\begin{array}{l}\text { Lev } \\
\text { Te } \\
\text { Equ } \\
\text { Var }\end{array}$ & $\begin{array}{l}\text { he's } \\
\text { for } \\
\text { ty of } \\
\text { aces }\end{array}$ & \multicolumn{7}{|c|}{ t-test for Equality of Means } \\
\hline & & \multirow[t]{2}{*}{$\mathrm{F}$} & \multirow[t]{2}{*}{ Sig. } & \multirow[t]{2}{*}{$\mathrm{t}$} & \multirow[t]{2}{*}{$\mathrm{df}$} & \multirow[t]{2}{*}{$\begin{array}{l}\text { Sig. (2- } \\
\text { tailed) }\end{array}$} & \multirow[t]{2}{*}{$\begin{array}{c}\text { Mean } \\
\text { Differen } \\
\text { ce }\end{array}$} & \multirow{2}{*}{$\begin{array}{c}\text { Std. } \\
\text { Error } \\
\text { Differen } \\
\text { ce }\end{array}$} & \multicolumn{2}{|c|}{$\begin{array}{l}\text { 95\% Confidence } \\
\text { Interval of the } \\
\text { Difference }\end{array}$} \\
\hline & & & & & & & & & Lower & Upper \\
\hline $\begin{array}{c}\text { HASIL } \\
\text { BELAJA }\end{array}$ & $\begin{array}{c}\text { Equal } \\
\text { variance } \\
\mathrm{s} \\
\text { assumed }\end{array}$ & .903 & .350 & -3.528 & 28 & .001 & $\begin{array}{l}- \\
8.80000\end{array}$ & 2.49444 & $\begin{array}{l}- \\
13.909 \\
63\end{array}$ & -3.69037 \\
\hline $\begin{array}{c}\text { R } \\
\text { PSIKOM } \\
\text { OTORIK }\end{array}$ & $\begin{array}{c}\text { Equal } \\
\text { variance } \\
\text { s not } \\
\text { assumed }\end{array}$ & & & -3.528 & $\begin{array}{l}27.72 \\
1\end{array}$ & .001 & $\begin{array}{l}- \\
8.80000\end{array}$ & 2.49444 & $\begin{array}{l}- \\
13.911 \\
95\end{array}$ & -3.68805 \\
\hline
\end{tabular}

Tabled used by permission Fardila, Susi. 2021. Data hasil uji Independent Sample T-test Hasil Belajar Kognitif

Hasil nilai Sig. (2 tailed) antara kelas kontrol dan kelas eksperimen adalah 0.001 yang berarti nilai ini kurang dari $0,05(0.001<0,05)$ dapat diartikan, bahwa terdapat perbedaan yang sangat signifikan pada hasil belajar kognitif peserta didik antara kelas kontrol dan kelas eksperimen. 


\subsubsection{Uji N-gain}

Uji N-gain dilakukan jika terdapat pengaruh signifikan sebelum dan sesudah implementasi media pembelajaran yang dikembangkan. Uji peningkatan rata-rata dilakukan untuk mengetahui besarnya peningkatan hasil belajar peserta didik kelas kontrol dan kelas eksperimen menggunakan MoLfAS.

$<g>=\frac{\text { Skor kelas eksperimen }- \text { Skor kelas kontrol }}{\text { Skor ideal }- \text { Skor kelas kontrol }}$

$<g>=\frac{1334-1202}{1500-1202}$

$<g>=0,4$

Berdasarkan perhitungan diatas nilai hasil belajar peserta didik kelas kontrol dan kelas eksperimen diperoleh nilai n-gain sebesar 0,4 atau dapat disimpulkan bahwa peningkatan hasil belajar peserta didik dalam kategori sedang. Peningkatan hasil belajar peserta didik ini sejalan dengan peneltian sebelumnya yang dilakukan oleh (Utama and Mashfuhah, 2016) dengan hasil belajar peserta didik meningkat dan peserta didik memberikan respon positif terhadap media pembelajaran articulate storyline dan implementasinya, serta penelitian oleh (Pratama, 2019) capaian hasil belajar siswa juga menunjukkan rata-rata di atas 75 , dengan demikian aplikasi dapat dikatakan layak digunakan sebagai media pembelajaran.

\section{Simpulan}

Penelitian dan pengembangan ini menghasilkan Mobile Learning Interaktif berbasis Articulate Storyline 3 untuk meningkatkan self-regulated learning dan hasil belajar peserta didik pada mata pelajaran Kearsipan X OTKP di SMK Cendika Bangsa Kepanjen. Media Pembelajaran ini bernama MoLfAS (Mobile Learning for Archive Storage) yang dapat diunduh secara gratis melalui link: https://bit.ly/apkMoLfAS.

Media pembelajaran pada penelitian ini telah dinyatakan 'Sangat Valid' dan layak digunakan dalam pembelajaran Kearsipan melalui validasi ahli materi dan ahli media serta uji coba kelompok kecil. Selain itu, MoLfAS telah terbukti efektif dalam meningkatkan selfregulated learning dan hasil belajar peserta didik berdasarkan hasil uji independent sample ttest dan uji n-gain. MoLfAS memungkinkan kegiatan pembelajaran dapat dilakukan kapanpun dan dimanapun, bahkan dapat dilakukan secara mandiri oleh pengguna, dan sangat cocok digunakan dilakukan saat pembelajaran daring.

MoLfAS yang dikembangkan memuat satu kompetensi dasar pada mata pelajaran Kearsipan, sehingga diharapkan peneliti selanjutnya untuk mengembangkan mobile learning ini tidak hanya terbatas pada satu kompetensi dasar saja, melainkan dapat digunakan secara penuh dalam satu semester dengan meminimalisir ukuran aplikasi, perekapan nilai dapat terintegrasi otomatis dengan Microsoft excel untuk memudahkan guru pengajar, serta aplikasi dapat dipublish pada Google Play Store, sehingga aplikasi lebih mudah untuk ditemukan pengguna lebih luas. 


\section{Daftar Rujukan}

Alhafidz, M. R. L. And Haryono, A. (2018) 'Pengembangan Mobile Learning Berbasis Android Sebagai Media Pembelajaran Ekonomi', Jurnal Pendidikan Ekonomi, 2, pp. 118-124.

Andito, M. S. R. And Supriadi, D. (2020) 'Pengembangan Media Pembelajaran Interaktif Materi Keterampilan Kepramukaan Golongan Penegak Dalam Kegiatan Pengembaraan’ Educate: Jurnal Teknologi Pendidikan, 5(1), 73-85.

Arwanda, P., Irianto, S. and Andriani, A. (2020) 'Pengembangan Media Pembelajaran Articulate Storyline Kurikulum 2013 Berbasis Kompetensi Peserta Didik Abad 21 Tema 7 Kelas Iv Sekolah Dasar', AlMadrasah: Jurnal Pendidikan Madrasah Ibtidaiyah, 4(2), p. 193-204. doi: 10.35931/am.v4i2.331.

Boekaerts, M. (1999) 'Self-Regulated Learning: Where We Are Today', International Journal of Educational Research, 31(6), Pp. 445-457. Doi: 10.1016/S0883-0355(99)00014-2.

Cheng, C. K. E. (2011) 'The role of self-regulated learning in enhancing learning performance', (January 2011).

Fitriyani, R., \& Fernandes, R. (2020). Pelaksanaan Student Centered Learning Berbasis Online pada Pembelajaran Sosiologi Siswa Kelas X IPS SMA Negeri 4 Bukittinggi Masa Pandemi Covid-19. Jurnal Sikola: Jurnal Kajian Pendidikan dan Pembelajaran, 2(1), 8-18.

Ghozali, F. A. And Rusimamto, P. W. (2016) 'engembangan Media Pembelajaran Berbasis Articulate Studio'13 Kompetensi Dasar Arsitektur dan Prinsip Kerja Fungsi Setiap Blok Plc Di Smk Negeri 1 Sampang', Jurnal Pendidikan Teknik Elektro, 1.5(1).

Jalinus, N., \& Ambiyar, A. (2016). Media dan sumber pembelajaran. (Accessed: 8 October 2020).

KEBUDAYAAN, M. P. D., \& INDONESIA, R. (2020). Surat Edaran Nomor 4 Tahun 2020 Tentang Pelaksanaan Kebijakan Pendidikan Dalam Masa Darurat Penyebaran Coronavirus Disease (COVID-19).

Kristiyani, T. (2016) Self Regulated Learning: Konsep, Implikasi, Dan Tantangannya Bagi Siswa Di Indonesia, Sanata Dharma University Press, Yogyakarta. Sanata Dharma University Press. Available At: Https://Repository.Usd.Ac.Id/36041/ (Accessed: 7 October 2020).

Marlina (2017) 'Increasing Self Regulated Learning Of Students With Special Needs Through The Ilbawel Model', Journal Of Icsar, 1(1), Pp. 72-80. Doi: 10.17977/Um005v1i12017p072.

Mas'adah (2019) 'Development of Guided Inquiry Learning Model by Articulate Storyline Media on Elasticity Materials To Increase Student 's Motivation And Learning Achievement', International Journal of Scientific and Research Publication, 12, pp. 432-438.

Meolbatak, E. M. and Bria, Y. P. (2016) 'Penerapan Model Multimedia Sebagai Media Pembelajaran Alternatif untuk Meningkatkan Self Motivated Learning gan Self Regulated Learning', Media Teknika Jurnal Teknologi, 11(2), pp. 83-90.

Mumtahana, A. (2020) 'Development of Learning Content in Computer Based Media with Articulate Storyline to Improve Civiccs Learning Outcomes in Third Grade Elementary School Students', International Journal of Innovative Science and Research Technology, 5(2), p. 777.

Nabilah, C. H., Sesrita, A. and Suherman, I. (2020) 'DEVELOPMENT OF LEARNING MEDIA BASED ON ARTICULATE', Indonesian Journal of Applied Research (IJAR), 2, pp. 80-85.

Pratama, R. A. (2019) 'Media Pembelajaran Berbasis Articulate Storyline 2 pada Materi Menggambar Grafik Fungsi Di Smp Patra Dharma 2 Balikpapan', Jurnal Dimensi, 7(1), pp. 19-35. doi: 10.33373/dms.v7i1.1631.

Rafmana, H. and Chotimah, U. (2018) 'Pengembangan Multimedia Interaktif Berbasis Articulate Storyline Untuk Meningkatkan Motivasi Belajar Siswa Pada Mata Pelajaran PKn Kelas XI Di SMA Srijaya Negara Palembang', Jurnal Bhinneka Tunggal Ika, 05(1), pp. 52-65. Available at: https://ejournal.unsri.ac.id/indeks.php/jbti/ article/download/7898/pdf.

Rahmat, R. F. et al. (2019) 'Pengembangan media pembelajaran berbasis mobile learning pada mata pelajaran simulasi digital', Jurnal Inovasi Teknologi Pendidikan, 6(2), pp. 116-126. doi: 10.21831/jitp.v6i2.27414.

Rizal, H., Satrio, A. and Wirawan, P. W. (2013) 'Perancangan dan Pembuatan Mobile Learning Interaktif Berbasis Android Dengan Metode Personal Extreme Programming', Jurnal Masyarakat Informatika, 4(8), Pp. 21-26. Doi: 10.14710/Jmasif.4.8.21-26.

Rohmah, F. N. and Bukhori, I. (2020) 'Pengembangan Media Pembelajaran Interaktif Mata Pelajaran Korespondensi Berbasis Android Menggunakan Articulate Storyline 3', Economic \& Education Journal, 2, pp. 169-182. 
Jurnal Ekonomi, Bisnis dan Pendidikan, 1(4), 2021, 344-356

Saefi, M., Lukiati, B. and Suarsini, E. (2017) ‘Developing Android-Based Mobile Learning On Cell Structure And Functions Lesson Subject Topic To Optimize Grade XI Students' Cognitive Comprehension', Jurnal Pendidikan Sains, 19(2), pp. 57-63. Available at: http://journal.um.ac.id/index.php/jps/.

Sudjana (2014) Penilaian Hasil Proses Belajar Mengajar. 18th Edn. Bandung: Remaja Rosdakarya.

Sugiyono, P. D. (2015). Metode Penelitian Pendidikan Pendekatan Kuantitatif, Kualitatif, dan R\&D Bagian III.

Utama, C. and Mashfuhah, A. (2016) 'Implementasi Media Pembelajaran Articulate Studio untuk Meningkatkan Hasil Belajar Siswa', Jurnal Pena Sains, 3(1), pp. 21-29. Doi: 10.21107/Jps.V3i1.1297 